\title{
THE CHALLENGES FACED BY THE ENFORCEMENT BODIES IN MALAYSIA ON HUMAN TRAFFICKING
}

\author{
Zuraini Ab Hamid ${ }^{1 *}$, Noor Shuhadawati Mohamad Amin², Norjihan Ab Aziz \\ ${ }^{1 *}$ Dr., International Islamic University Malaysia, MALAYSIA, zurainihamid@iium.edu.my \\ ${ }^{2}$ Mrs., International Islamic University Malaysia, MALAYSIA, shuhadaamin@iium.edu.my \\ ${ }^{3}$ Dr., International Islamic University Malaysia, MALAYSIA, noriihanabaziz@iium.edu.my \\ ${ }^{*}$ Corresponding Author
}

\begin{abstract}
Excellence in the implementation of the legal framework on human trafficking by the enforcement bodies is one important benchmark that determines the success of Malaysia in the Trafficking in Persons (TIP) Report. The responsibility to enforce this framework is led by the Royal Malaysian Police (RMP) followed by the Immigration Department, the Customs Department, the Malaysian Maritime Enforcement Agency (MMEA), and the Department of Labour. Accordingly, Anti-Trafficking in Person unit is established in each body to acknowledge the power and trust granted to them. Normally located at the headquarters, these specialised units are dedicated to combat human trafficking. Furthermore, their actions are within the ambit of power granted by the legislated laws, particularly in Anti-Trafficking in Persons and Anti-Smuggling of Migrants Act 2007 (ATIPSOM 2007). All forms of exploitation including sex exploitation, labour force, and selling of babies which are common in Malaysia are highlighted by the Act. Unfortunately, since the introduction of TIP in 2001, these bodies have been continuously criticised by the reports, media, non-governmental organisations (NGOs), and public for their deficiency in identifying the vulnerable victims, detecting corruption among their officers, and failure in investigating the related cases. This article studies the power of these five enforcement bodies and the challenges that they face in combatting the heinous crime in order to understand the factors influencing their incompetency. A combination of content analysis and semistructured interview was adopted in the research. On the whole, the article contends that a lot of improvements need to be done to recuperate the image of these enforcement bodies and to strengthen their fight against human trafficking in Malaysia.
\end{abstract}

Keywords: Human trafficking, enforcement bodies, Malaysia, challenges

\section{INTRODUCTION}

The fight against human trafficking in Malaysia is an endless battle. The country is regarded as a destination, source, and transit country for human trafficking and consequently, has been severely affected by this crime. Notably, the government of Malaysia has taken continuous efforts to combat human trafficking especially through strengthening the enforcement of its legal framework. This effort is executed by conducting 
awareness programs for government officers; implementing attendance of investigation and prosecution trainings in the country and abroad to the entire enforcement agencies; and providing discussions, forums, and seminars for senior government officers.

Consequently, these efforts had been proven to be effective as shown by the significant decline in the number of trafficking offences in the statistics of 2011 compared to the previous year, 2010. The most significant factors contributing to this decline were the effective coordination and integrated efforts by the Malaysian enforcement agencies. Nonetheless, the positive result failed to continuously strengthen Malaysia's position in the TIP Report. From 2011 until 2016, the Malaysian government had been ranked in Tier 2 and Tier 3 in the TIP Reports provided by the Department of State Office to Monitor and Combat Trafficking in Persons, U.S. Department. These rankings demonstrated that Malaysia had improved its enforcement of laws to prevent human trafficking, but the efforts were still insufficient.

Apart from that, the TIP Reports from 2012 until 2016 further outlined that Malaysian front line officials lack the ability to identify the indicators of human trafficking and had not received adequate training to deal with trafficking victims and anti-trafficking procedures. As a result, they had exposed the victims to legal actions and failed to investigate the complaints made by the victims. In addition, the enacted laws in Malaysia were claimed to not protect the domestic workers from Indonesia as several of the victims were misidentified as criminals and detained by the immigration authorities after being arrested.

Furthermore, several government officers in few ASEAN countries including Malaysia were found to be complicit with the crime and are still making profit from the trafficking activities. These countries also refuse to provide basic financial aid and sufficient resources to ensure the effectiveness of their enforcement bodies and judicial systems. Apart from that, the Human Rights Commission of Malaysia (SUHAKAM) claimed that the Malaysian law enforcement has only emphasised on the investigation but not the prevention of human trafficking. As a result, the enforcement officers have been labelled as incompetent, unprofessional, and unethical.

The adverse comments presented by the TIP reports, NGOs, and media on the enforcement bodies in Malaysia have prompted a research on their powers and the challenges that limit their effectiveness in combatting the crime. The first part of this article explains the inherent powers conferred to the five enforcement bodies in relation to human trafficking and subsequently, outlines the challenges that they face in the fight against human trafficking.

\section{THE ENFORCEMENT BODIES IN MALAYSIA}

The powers to tackle and manage human trafficking issues vested on the five enforcement bodies in Malaysia are governed by ATIPSOM 2007 and particular Acts. Section 2 of ATIPSOM 2007 defined an "enforcement officer" as any officer specified in Section 27 which refers to any police officer, immigration officer, customs officer, MMEA officer, or Labour Office officer. By virtue of Section 6 (2) (i) of the Act, they are officially recognised as the bodies governing the human trafficking issues. Moreover, these bodies are led by the Council for Anti-Trafficking in Persons and Anti-Smuggling of Migrant which is also known as Majlis Antipemerdagangan Orang (MAPO). This council and the bodies coordinate the implementation of ATIPSOM 2007 and formulate policies to prevent human trafficking and smuggling.

Notably, all of the five enforcement bodies in Malaysia have four main functions in combatting human trafficking: to rescue, to investigate, to arrest, and to prevent. These powers are further embodied under Section 27 of ATIPSOM 2007 which include (i) the power of investigation; (ii) the power to arrest without a warrant; (iii) the power to search and seize with a warrant; (iv) the power to search and seize without a warrant; (v) the power to access computerised data; (vi) the power to examine persons; and (vii) the power to forfeit conveyance and movable property.

Apart from the principal Act, some of the bodies are also led by their own Acts. For example, MMEA is governed by Malaysian Maritime Enforcement Agency Act 2004 (Act 633); their powers, jurisdictions, and responsibilities are stated clearly in this Act. In addition, the Immigration Department is governed by Immigration Act 1959/63 and the RMP is governed by Police Act 1967. In the absence of any specific Act to govern the crimes, the Department of Labour Peninsular Malaysia and the Royal Malaysian Customs are fully governed by ATIPSOM 2007.

\subsection{Number of Human Trafficking Cases Raided by Enforcement Bodies}

The enforcement bodies in Malaysia have conducted many extensive raids to prevent human trafficking. Approximately (847) raid cases by the enforcement bodies were recorded from 2008 until 2014 and the highest rate was seen in the year 2012. 
IJASOS- International E-Journal of Advances in Social Sciences, Vol. III, Issue 7, April 2017

Table 2.1

Statistic on the cases handled by the enforcement bodies in Malaysia from 28.02.2008- 30.09.2014

\begin{tabular}{|c|c|c|c|c|c|c|c|c|}
\hline \multirow{2}{*}{$\begin{array}{c}\text { ENFORCEMENT } \\
\text { BODIES }\end{array}$} & \multicolumn{6}{|c|}{ RAID CASES FOR TRAFFICKING IN PERSON } \\
\cline { 2 - 9 } & $\mathbf{2 0 0 8}$ & $\mathbf{2 0 0 9}$ & $\mathbf{2 0 1 0}$ & $\mathbf{2 0 1 1}$ & $\mathbf{2 0 1 2}$ & $\mathbf{2 0 1 3}$ & $\mathbf{2 0 1 4}$ & TOTAL \\
\hline $\begin{array}{c}\text { ROYAL POLICE } \\
\text { MALAYSIA }\end{array}$ & 15 & 127 & 104 & 86 & 140 & 82 & 112 & 666 \\
\hline $\begin{array}{c}\text { IMMIGRATION } \\
\text { DEPARTMENT }\end{array}$ & 2 & 24 & 20 & 26 & 48 & 17 & 16 & 153 \\
\hline $\begin{array}{c}\text { ROYAL } \\
\text { MALAYSIAN } \\
\text { CUSTOM }\end{array}$ & 0 & 0 & 2 & 0 & 0 & 0 & 0 & 2 \\
\hline $\begin{array}{c}\text { MARITIME } \\
\text { ENFORCEMENT } \\
\text { AGENCY }\end{array}$ & 0 & 0 & 6 & 1 & 0 & 0 & 1 & 8 \\
\hline $\begin{array}{c}\text { DEPARTMENT } \\
\text { OF LABOUR }\end{array}$ & 0 & 0 & 0 & 4 & 7 & 1 & 6 & 18 \\
\hline $\begin{array}{c}\text { TOTAL } \\
\text { AMOUNT }\end{array}$ & 17 & 151 & 132 & 117 & 195 & 100 & 135 & 847 \\
\hline
\end{tabular}

Source: MAPO

The data above proved that the human trafficking cases had been comprehensively investigated from the year 2008, after the introduction of ATIPSOM 2007. Notably, the RMP performed the highest number of raids, proving their extensive efforts in combatting the crime. Conversely, the Royal Malaysian Customs handled the least number of cases on human trafficking and this may be explained by their main job scope which is to deal with goods instead of human beings. Apart from that, the first human trafficking case by the Department of Labour was noted in 2011 because the department had no authority to carry out an investigation prior to 2010. The power to handle cases of exploitation for forced labour was granted to the department in 2010 with the amendment on Section 27 of ATIPSOM 2007.

\section{PROBLEMS AND CHALLENGES FACED BY THE ENFORCEMENT BODIES}

The enforcement officers have undergone numerous trainings, extended cooperation, and exerted efforts to combat the human trafficking crime. Nevertheless, two crucial factors limit the execution of their duties, namely lack of manpower and expertise, and insufficient basic facilities.

\subsection{Manpower and Expertise}

The lack of manpower and expertise is dire in all of the five Malaysian enforcement bodies. Notably, each of the bodies has their own main job scope to be fulfilled. The task to handle cases of human trafficking is an additional job scope that has increased their responsibilities. Plus, the human trafficking case requires different procedures as compared to their normal job scope.

For example, the investigation officer $(\mathrm{IO})$ has to ensure that the trafficking victim is protected at a shelter after being rescued. This process requires the IO to obtain an Interim Protection Order (IPO) within 24 hours and a Protection Order (PO) from the court which may take more than two weeks. At the same time, the IO is responsible to complete the investigation paper, ensure the victim attends the court as a witness, and escort the victim for treatment at the hospital. These steps are not necessary in other criminal cases where the victim can return home once he lodged a report against the accused.

Additionally, the IO in RMP has to handle more than one criminal case per day. As the 10 receives other criminal cases such as rape, robbery, or murder, an investigation paper needs to be opened and the 10 
should collect material evidences, note the statement from the witness, arrest the accused person, visit the crime scene to collect evidences, and ultimately, complete the investigation paper. This investigation procedure takes more than a day and may extend to months, especially if it involves formal reports from the chemistry or forensic department.

MMEA faces similar problems as the agency was recently established in the year 2005 and hence, has insufficient number of officers and suffers from lack of expertise. Despite attending few trainings, the IOs still face difficulties in conducting investigations on the trafficking cases such as in recording a victim's statement and in collecting evidences. Another significant example is MMEA in Sabah that has no specific unit to handle human trafficking cases even though Sabah is separated by the South China Sea (Laut China Selatan) from Peninsular Malaysia. Consequently, the branch has to contact the specialised unit at Putrajaya when they require assistance from the expert. The situation worsens when the responsibility is shifted to the customs officers because their expertise lies in dealing with goods instead of human beings. Moreover, inspections in Sabah and Sarawak are more challenging as large coastal and land areas need to be covered.

\subsection{Basic Facilities}

The enforcement bodies should be equipped with adequate facilities to ensure their success in combatting the human trafficking crime. In addition to weapons, they require financial support, transportation, shelters, interpreters, and proper instruments. All of these facilities are important to ensure that the investigations are properly conducted and the victims are well protected.

\subsubsection{Transportation}

The $I O$ is responsible to ensure that the victim from the shelter attends the court but the problem arises if the shelter is located far from the court. The $\mathrm{IO}$ has to arrange for transportation and escort officers for the victim and this becomes more difficult when various locations are involved. A typical trafficking case handled by an IO of the RMP in Malaysia is explained further in the following scenario. In this case, the First Information Report about the missing of a victim from her house was received by an $\mathrm{IO}$ at his office which is located in Negeri Sembilan. Subsequently, the victim was found and saved in Selangor. The investigation disclosed that the victim was exploited for sexual commercial in Selangor.

Consecutively, a PO was granted by the Magistrate Court to place the victim at a female shelter in Johor. Nonetheless, the trial for this case was heard in Selangor. Notably, this particular case involved three different places. The $1 \mathrm{O}$ needed to arrange for transportation and escort officers from Negeri Sembilan to collect and return the victim and her welfare officers from Negeri Sembilan to Johor, from Johor to Selangor, and from Selangor to Johor. At times, the DPP and officers of court need to delay the case for several hours to wait for their arrival.

Apart from that, no proper transit is available for the victim. No specific waiting room is prepared for the victim in the event that she arrives at the court early. Most courts in Malaysia do not have a witness room like the one available in the Kuala Lumpur court. Consequently, the victim is tired from walking and sitting around the court. This situation would affect the victim's emotion by the time she is needed to give a testimony against the trafficker.

The same problem is also faced by the Labour Department. As a new member to MAPO, it has less logistic facilities compared to the RMP or Immigration Department. In one incident, the department had to inquire for assistance from another agency to transport a large number of victims from one state to another.

Additionally, the Customs Department also faced the same experience in a case involving (40) suspected victims in Selangor. The officers needed to transport all of the victims using few cars and consequently, waste their time, manpower, and costs, as well as burdening many parties.

\subsubsection{Temporary Shelter for Victim}

Once the victims are brought before the office for the purpose of investigation, problems arise. All the bodies do not have a specific place or temporary shelter to locate the victim. Most of the time, the department itself becomes the shelter for the victims where the victims would sleep and eat during the investigation process while waiting for an IPO. In this situation, the IO's office will be crowded. Among the factors which contribute to this situation is due to the procedures which require the $I O$ to identify the victim of human trafficking within (24) hours. Within this time, the 10 should determine whether the victim is a trafficking victim or not before deciding whether to apply IPO for victim, to free him or to charge him for a different offence. 


\subsubsection{Financial Support}

As for the enforcement bodies, even though they have received the financial budget, the budget is limited to their core responsibilities where handling human trafficking cases is not part of it. For example, the core responsibility for the Customs Department is to deal with goods, not with human trafficking cases. Therefore, in this situation, it is a challenge for the body to locate the budget for human trafficking cases. In the absence of any additional budget, it is difficult for them to support the additional tasks which only come to their attention after the introduction of the ATIPSOM 2007. The absence of funds has restricted the enforcement bodies in sharing of knowledge to the other officers. Even though they can utilise their department budget in conducting in house training, it is still limited to a small number of participants.

\subsubsection{Interpreter}

An interpreter is required for a human trafficking case since the crime is transnational in nature. The victims and the accused come from various countries with various languages and backgrounds. For example this problem is faced by the MMEA where the victims or the accused are from various countries such as Afghanistan, Pakistan and Myanmar. They cannot even speak English. Sometime, it would take time for the maritime officer to find the interpreters for the purpose of communication. Sometimes, the department tries to get help from the embassy based on the victim's citizenship. However, there are few cases where the embassies itself do not understand the language or dialect used by the suspected victims.

\subsubsection{Lack of proper Instrument}

Some departments such as MMEA needs sophisticated instruments to fight the crime. For example, the MMEA have five regions of jurisdiction nationwide, involving $4,492 \mathrm{~km}$ of coast line. In this situation, sea surveillance using ships is no longer relevant to secure the Malaysian border. Multiple exit points operated by various facilitators have made the situation become worse. The syndicate might use sophisticated and highspeed boats with four engines each with (300) horsepower. This is among the reasons why MMEA has difficulty to eradicate the trafficking activities and smuggling through the sea. Therefore, sophisticated instrument such as drones as eyes in the sky is a need to improve the department's operational efforts on its surveillance of the Malaysian waters to fight the crime, smuggling and intrusion at sea.

\section{CONCLUSION}

This article discloses that there are two main limitations which contributed to the lack of effectiveness of enforcement bodies in combatting the crime and enforcing the written legal framework. They are due to lack of manpower and expertise, and basic facilities. Regrettably, these weaknesses are due to the lack of resources either in the form of qualified officers or financial support. This is the crucial reason limiting enforcement officers in carrying their duties. Therefore, these issues must be focused on to ensure the success of the enforcement bodies in combatting the crime.

The government of Malaysia should give its quick response on this. All the (5) enforcement bodies should be given adequate manpower and expertise based on their needs. This could be done by appointing more specialised officers to handle human trafficking cases, and provide them with relevant training. The government should also provide facilities especially transportation, shelter, financial support, proper instruments and interpreters to the enforcement bodies to ensure their work proceeds smoothly without any problems. Regarding these needs, an assessment committee such as MAPO should be appointed to identify their requirements. The allocation of budget by Minister of Finance should consider that all the bodies should receive direct financial assistance from the ministry based on their necessities. At the same time, the National Audit Department can continue to audit the use of the budget.

\section{ACKNOWLEDGEMENT}

This research was financially supported by the International Islamic University Malaysia Research Initiative Grant Scheme (RIGS16-058-0222). 


\section{REFERENCE LIST}

977 Mangsa Jenayah Pemerdagangan Manusia Diselamatkan, Berita Harian <http://www. bharian.com.my/bharian/articles/977mangsajenayahpemerdaganganmanusiadiselamatkan/Article/inde x_html> (accessed 2 May, 2016).

Alice Huling, "Domestic Workers in Malaysia: Hidden Victims of Abuse and Forced Labor", New York University Journal of International Law \& Politics, vol. 44, (2012): 629-679.

Anonymous, Interviewed by Author, Ampang Sesion Court, Selangor, 8 April 2014.

Anonymous, Interviewed by Author, Department of Custom (Dengkil), Selangor, 22 April 2014.

Anonymous, Interviewed by Author, Malaysia Maritime Enforcement Agency, Sabah, 5th May 2014.

Anonymous, Interviewed by Author, Malaysia Maritime Enforcement Agency, Putrajaya, 28th February 2014.

Anonymous, Interviewed by Author, Police Head Quarters, Ampang, Selangor, 21st April 2014.

Anti-Trafficking In Persons and Anti-Smuggling of Migrants Act 2007 (Act 670).

Cf M Y Mattar. (2003). Trafficking in persons, especially women and children, in countries of the middle east: The scope and problem and the appropriate legislative responses. Fordham International Law Journal, Vol. 26, 721-727.

Farik Zolkepli and Austin Camoens. (2014, February 6). Eyes and the Sky for MMEA, The Star, p. 16 Malaysian Maritime Enforcement Agency Act 2004

Mindy M. Willman, "Human Trafficking In Asia: Increasing Individual and State Accountability Through Expanded Victims' Rights", Columbia Journal of Asia Law, vol. 22, no. 2 (2009): 284-313.

P.R Gunarajan. (2013, September). Organised Crime: Government Initiatives, Laws and Investigation of Human Trafficking in Person and Smuggling of Migrants in Malaysia. Paper presented at International Conference on Trafficking organised by World Youth Foundation, Malacca.

Protocol to Prevent, Suppress and Punish Trafficking in Persons, Especially Women and Children, Supplementing the United Nations Convention Against Transnational Organized Crime, G.A. Res. 25, annex II, U.N. GAOR, 55th Sess., Supp. No. 49, at 60, U.N. Doc. A/55/49 (Vol. I) (2001).

Report by Human Rights Commission of Malaysia (SUHAKAM) in Trafficking in Women and Children Published by Human Rights Commission of Malaysia (SUHAKAM), Kuala Lumpur: 2011.

Royal Malaysian Police. (2013). Organised Crime: Government Initiatives, Laws and Investigation of Human Trafficking in Person and Smuggling of Migrants in Malaysia. Paper presented at International Conference on Trafficking organized by World Youth Foundation, Malacca.

Trafficking in Persons Report 2012, U. S Department of State, <http://www.state.gov/j/ tip/rls/tiprpt /2012/192363.htm> (accessed 2 September, 2012).

Trafficking in Persons Report 2013, U.S. Department of State, <http://www.state.gov/j/ tip/rls/tiprpt/2013/210548.htm> (accessed 24 September, 2013).

Trafficking in Persons Report July 2015," U.S Department of State, accessed Nov 29, 2015, https://www.state.gov/documents/organization/245365.pdf.

Trafficking in Persons Report July 2016, US Department of State, https://www.state.gov/documents/organization/258880.pdf (accessed 14 December, 2016).

Trafficking in Persons Report June 2014, U.S Department of State. <http://www.state.gov/ documents/organisation/226847.pdf> (accessed on 27 June, 2014).

Trafficking in Persons Report, U.S Department of State. <http://www.state.gov/j/tip/rls/tiprpt/ 2010/> (accessed 24 May, 2014 